Prepared in cooperation with the Papio-Missouri River Natural Resources District

\title{
Flood-Inundation Maps for a 12.5-Mile Reach of Big Papillion Creek at Omaha, Nebraska
}

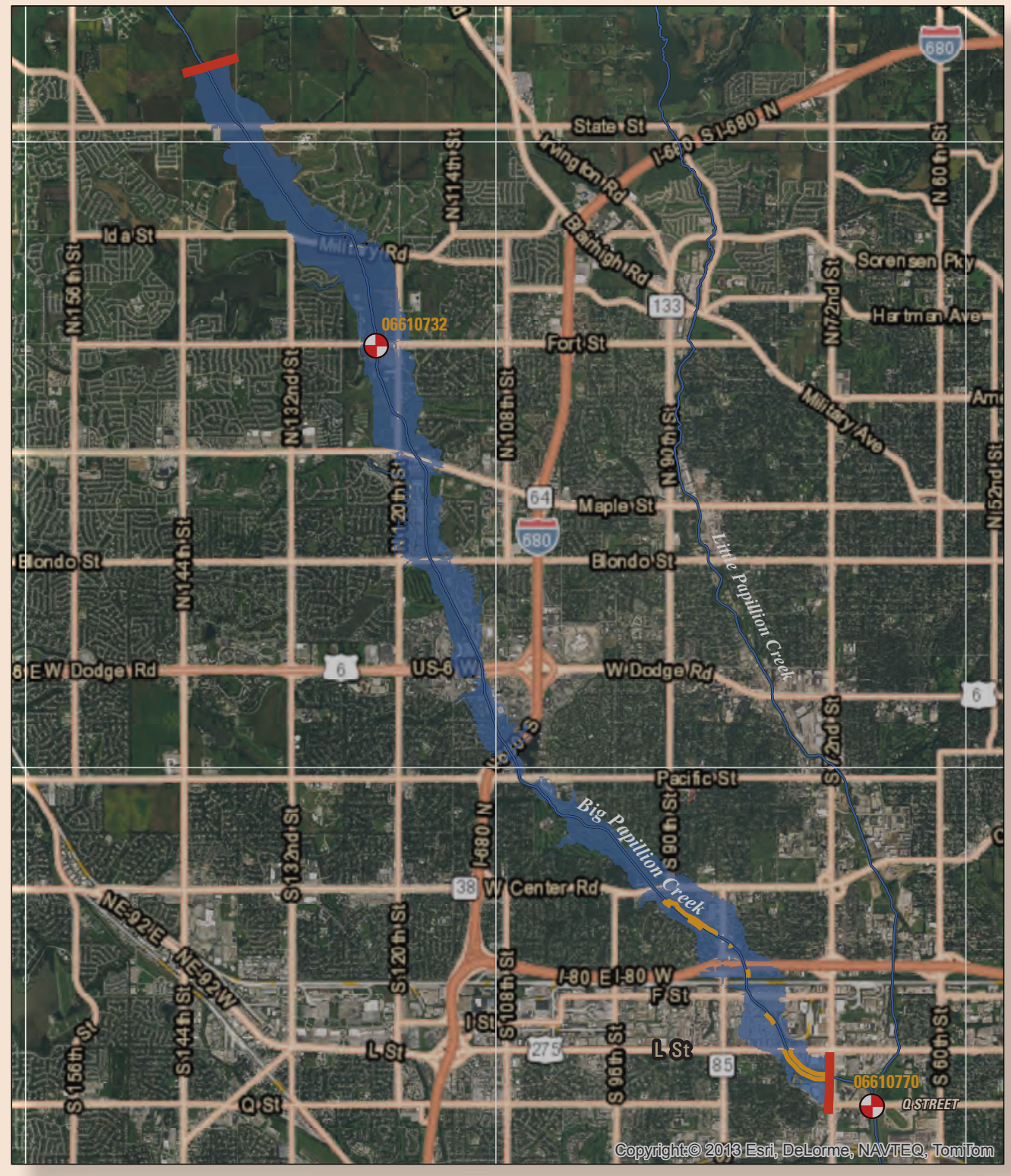

Scientific Investigations Report 2015-5152

U.S. Department of the Interior

U.S. Geological Survey 
Cover. Flood-inundation map for the Big Papillion Creek at Fort Street at Omaha, Nebraska, corresponding to a stage of 32.00 feet at the U.S. Geological Survey streamgage (station 06610732). 


\section{Flood-Inundation Maps for a 12.5-Mile Reach of Big Papillion Creek at Omaha, Nebraska}

By Kellan R. Strauch, Benjamin J. Dietsch, and Kayla J. Anderson

Prepared in cooperation with the Papio-Missouri River Natural Resources District

Scientific Investigations Report 2015-5052 


\title{
U.S. Department of the Interior SALLY JEWELL, Secretary
}

\section{U.S. Geological Survey Suzette M. Kimball, Director}

\author{
U.S. Geological Survey, Reston, Virginia: 2016
}

For more information on the USGS - the Federal source for science about the Earth, its natural and living resources, natural hazards, and the environment—visit http://www.usgs.gov or call 1-888-ASK-USGS.

For an overview of USGS information products, including maps, imagery, and publications, visit http://www.usgs.gov/pubprod/.

Any use of trade, firm, or product names is for descriptive purposes only and does not imply endorsement by the U.S. Government.

Although this information product, for the most part, is in the public domain, it also may contain copyrighted materials as noted in the text. Permission to reproduce copyrighted items must be secured from the copyright owner.

Suggested citation:

Strauch, K.R., Dietsch, B.J., and Anderson, K.J., 2016, Flood-inundation maps for a 12.5-mile reach of Big Papillion Creek at Omaha, Nebraska: U.S. Geological Survey Scientific Investigations Report 2015-5152, 11 p., http://dx.doi.org/10.3133/sir20155152.

ISSN 2328-0328 (online) 


\section{Acknowledgments}

The authors wish to thank the Papio-Missouri River Natural Resources District for funding the operation and maintenance of the streamgages used for this study. The authors would also like to thank the U.S. Army Corps of Engineers for providing the hydraulic models for the Big Papillion Creek and for assistance on the project. Special thanks are given to the National Weather Service for their continued support of the U.S. Geological Survey flood-inundation mapping program. 


\section{Contents}

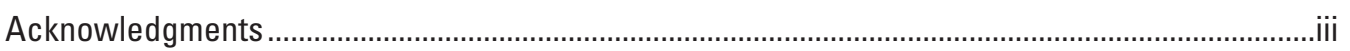

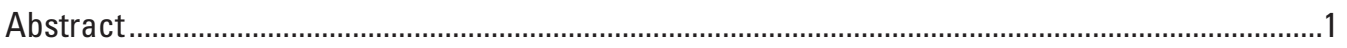

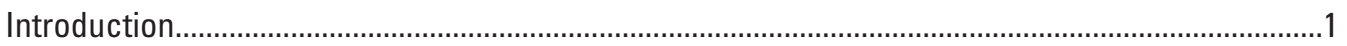

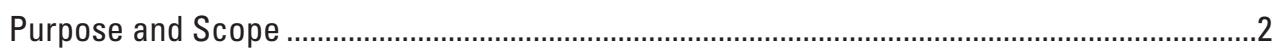

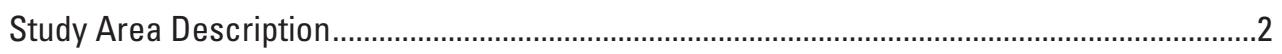

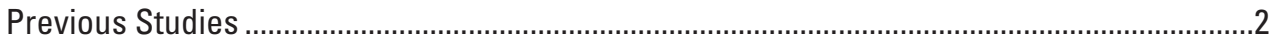

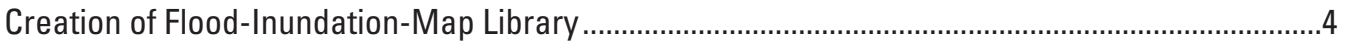

Computation of Water-Surface Profiles...............................................................................

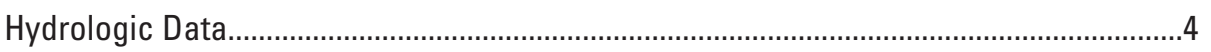

Topographic and Bathymetric Data .....................................................................

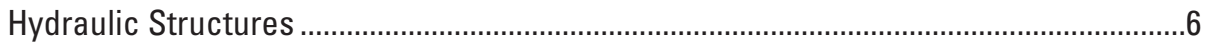

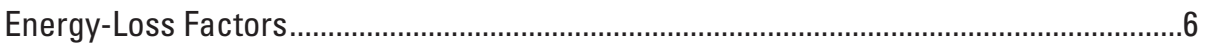

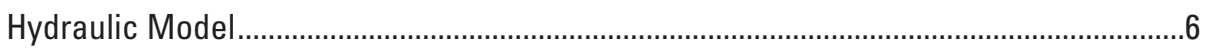

Development of Water-Surface Profiles.....................................................................

Development of Flood-Inundation Maps ..............................................................................

Flood-Inundation Map Delivery ...................................................................................

Disclaimer for Flood-Inundation Maps ............................................................................

Uncertainties and Limitations Regarding Use of Flood-Inundation Maps ........................

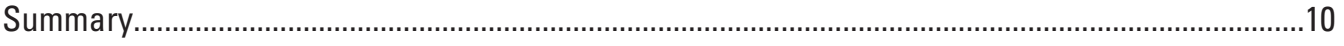

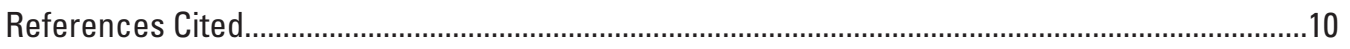

\section{Figures}

1. Map showing location of 12.5-mile study reach for the Big Papillion Creek at Omaha, Nebraska, and location of U.S. Geological Survey streamgages.

2. Flood-inundation map for the Big Papillion Creek at Fort Street at Omaha, Nebraska, corresponding to a stage of 32.00 feet at the U.S. Geological Survey streamgage (station 06610732) .

\section{Tables}

1. U.S. Geological Survey streamgage information for Big Papillion Creek at Omaha, Nebraska.

2. Peak discharges for selected annual exceedance probabilities for the Big Papillion Creek upstream from the confluence of the Big Papillion and Little Papillion Creeks .....4

3. Estimated discharges for corresponding stages and water-surface elevations at selected locations used in the hydraulic model of the Big Papillion Creek at Fort Street at Omaha, Nebraska.

4. Differences between observed (target) and simulated water-surface elevations at U.S. Geological Survey streamgage on Big Papillion Creek at Fort Street at Omaha, Nebraska (station 06610732)

5. Differences between observed (target) and simulated water-surface elevations at U.S. Geological Survey streamgage on Big Papillion Creek at 0 Street at Omaha, Nebraska (station 06610770) 


\section{Conversion Factors}

[Inch/Pound to International System of Units]

\begin{tabular}{lcl}
\hline \multicolumn{1}{c}{ Multiply } & By & \multicolumn{1}{c}{ To obtain } \\
\hline inch (in.) & Length & \\
foot (ft) & 2.54 & centimeter $(\mathrm{cm})$ \\
mile (mi) & 0.3048 & meter $(\mathrm{m})$ \\
& 1.609 & kilometer $(\mathrm{km})$ \\
\hline square $\mathrm{mile}\left(\mathrm{mi}^{2}\right)$ & Area & square kilometer $\left(\mathrm{km}^{2}\right)$ \\
\hline & 2.590 & \\
\hline cubic foot per second $\left(\mathrm{ft}^{3} / \mathrm{s}\right)$ & Flow rate & cubic meter per second $\left(\mathrm{m}^{3} / \mathrm{s}\right)$ \\
\hline & 0.02832 & \\
\hline foot per mile $(\mathrm{ft} / \mathrm{mi})$ & Hydraulic gradient & meter per $\mathrm{kilometer}(\mathrm{m} / \mathrm{km})$ \\
\hline
\end{tabular}

Vertical coordinate information is referenced to (1) stage, the height above an arbitrary datum established at a streamgage, and (2) elevation, the height above the North American Vertical Datum of 1988 (NAVD 88).

Horizontal coordinate information is referenced to the North American Datum of 1983 (NAD 83). 



\title{
Flood-Inundation Maps for a 12.5-Mile Reach of Big Papillion Creek at Omaha, Nebraska
}

\author{
By Kellan R. Strauch, Benjamin J. Dietsch, and Kayla J. Anderson
}

\section{Abstract}

Digital flood-inundation maps for a 12.5 -mile reach of the Big Papillion Creek from 0.6 mile upstream from the State Street Bridge to the 72nd Street Bridge in Omaha, Nebraska, were created by the U.S. Geological Survey (USGS) in cooperation with the Papio-Missouri River Natural Resources District. The flood-inundation maps, which can be accessed through the USGS Flood Inundation Mapping Science Web site at http://water.usgs.gov/osw/flood_inundation/, depict estimates of the areal extent and depth of flooding corresponding to selected water levels (stages) at the USGS streamgage on the Big Papillion Creek at Fort Street at Omaha, Nebraska (station 06610732). Near-real-time stages at this streamgage may be obtained on the Internet from the USGS National Water Information System at http://waterdata.usgs.gov/ or the National Weather Service Advanced Hydrologic Prediction Service at http:/water.weather.gov/ahps/, which also forecasts flood hydrographs at this site.

Flood profiles were computed for the 12.5 -mile reach by means of a one-dimensional step-backwater model. The model was calibrated by using the current (2015) stage-discharge relation at streamgages for the Big Papillion Creek at Fort Street at Omaha, Nebraska, and the Big Papillion Creek at Q Street at Omaha, Nebraska. The hydraulic model was then used to compute 15 water-surface profiles for flood stages at 1-foot (ft) intervals referenced to the streamgage datum for the Big Papillion Creek at Fort Street and ranging from $18 \mathrm{ft}$ (or near bankfull) to $32 \mathrm{ft}$, which exceeds the "major flood stage" as defined by the National Weather Service. The simulated water-surface profiles were then combined with a Geographic Information System digital elevation model (derived from light detection and ranging data having a 1.18 -ft vertical accuracy and 3.28-ft horizontal resolution) to delineate the area flooded at each flood stage (water level).

The availability of these flood-inundation maps, along with Internet information regarding current stage from the USGS streamgage and forecasted high-flow stages from the National Weather Service, will provide emergency management personnel and residents with information that is critical for flood response activities such as evacuations and road closures, as well as for postflood recovery efforts.

\section{Introduction}

The Papillion Creek Drainage basin is one of the most flood-prone and heavily populated areas in the State of Nebraska (Papio-Missouri River Natural Resources District, 2015). One of the most devastating floods happened on June 16th and 17th in 1964 in which 95 trailer homes were destroyed and washed downstream from a storm that produced 8 inches of rain in 3 hours, and the resulting flood waters destroyed houses and other personal property as well as resulted in the loss of seven lives (Papio-Missouri River Natural Resources District, 2015). Additional development and urbanization of the western part of the Papillion Creek Drainage basin since 1964 may cause a substantial increase in the amount of stormwater runoff (Papio-Missouri River Natural Resources District, 2015). This, in turn, could increase the severity and occurrence of flooding (Papio-Missouri River Natural Resources District, 2015).

Before this study, emergency responders in Omaha, Nebraska, relied on several information sources (all of which are available on the Internet) to make decisions on how to best alert the public and mitigate flood damages. One source is the Federal Emergency Management Agency flood insurance study (FIS) for Douglas County, which includes Omaha, dated December 2, 2005 (Federal Emergency Management Agency, 2005). A second source of information is the U.S. Geological Survey (USGS) streamgage, Big Papillion Creek at Fort Street at Omaha, Nebraska (station 06610732; hereafter referred to as Big Papillion Creek at Fort Street), from which current (U.S. Geological Survey, 2015a) and historical (since 2004; U.S. Geological Survey, 2015b) water levels and discharges, including annual peak flows, can be obtained. A third source of flood-related information is the National Weather Service (NWS) Advanced Hydrologic Prediction Service (AHPS), which displays the USGS stage data from the streamgage for the Big Papillion Creek at Fort Street and also issues stage forecasts for the Big Papillion Creek at Fort Street (National Weather Service, 2015a). The NWS does not routinely issue forecasts for the Big Papillion Creek at Fort Street, but it does so as needed during times of high flows (National Weather Service, 2015a). 
Although the current stage at a USGS streamgage is particularly useful for residents in the immediate vicinity of a streamgage, the stage is of limited use to residents farther upstream or downstream because the water-surface elevation is not constant along the entire stream reach. Knowledge of a water level at a streamgage is difficult to translate into depth and areal extent of flooding at points distant from the streamgage. One way to address these informational gaps is to produce a library of flood-inundation maps that are referenced to the stages recorded at the USGS streamgage. By referring to the appropriate map, emergency responders can discern the severity of flooding (depth of water and areal extent), identify roads that are or will soon be flooded, and make plans for notification or evacuation of residents in harm's way for some distance upstream and downstream from the streamgage. In addition, the capability to visualize the potential extent of flooding may motivate residents to take precautions and heed warnings that they previously might have disregarded. In 2014-15, the USGS, in cooperation with the Papio-Missouri River Natural Resources District, led a study to produce a library of flood-inundation maps for a 12.5-mile (mi) reach of the Big Papillion Creek in Omaha, Nebraska.

\section{Purpose and Scope}

This report describes the development of a series of estimated flood-inundation maps for a 12.5-mi reach of the Big Papillion Creek in Omaha, Nebraska, and identifies where on the Internet the maps can be found and ancillary data (Geographic Information System [GIS] flood polygons and depth grids) can be downloaded. The flood-inundation maps cover a 12.5-mi reach of the Big Papillion Creek from $0.6 \mathrm{mi}$ upstream from the State Street Bridge to the 72nd Street Bridge (fig. 1). The maps were produced for flood levels referenced to the stage recorded at the USGS streamgage on the Big Papillion Creek at Fort Street (station 06610732; table 1); the streamgage is located in the upstream one-half of the study reach. The maps cover a range in stage from 18 to 32 feet ( $\mathrm{ft}$ ) referenced to the streamgage datum. The 18 -ft stage is about bankfull and is defined by the National Weather Service (2015b) as the "action stage" or that stage which, when reached by a rising stream, requires the NWS or a partner to take some type of mitigation action in preparation for possible substantial hydrologic activity. The 32-ft stage exceeds the "major flood stage" as defined by the NWS and is between the water levels associated with the estimated 1- and 0.2-percent annual exceedance probability floods (floods with recurrence intervals between 100 and 500 years) (U.S. Army Corps of Engineers, Hydrologic Engineering Branch, Engineering Division, 2011).

\section{Study Area Description}

The Big Papillion Creek is in east-central Nebraska in the Western Corn Belt Plains ecoregion (Omernik, 1987). The drainage area ranges from 129 square miles $\left(\mathrm{mi}^{2}\right)$ at the streamgage for the Big Papillion Creek at Fort Street to $159 \mathrm{mi}^{2}$ at the downstream extent of the study reach. The headwaters originate in Washington County (not shown), and the creek flows generally south before entering the Omaha city limits. Once within the Omaha city limits, the stream flows in a southeasterly direction. No primary tributaries to the Big Papillion Creek join the main stem as it flows through the study reach; however, the Little Papillion Creek joins the main stem of the Big Papillion Creek downstream from the study reach limit. The basin terrain is characterized by gently rolling to moderately hilly topography. The study reach is approximately $12.5 \mathrm{mi}$ long and has an average top-of-bank channel width of about $130 \mathrm{ft}$ and an average channel slope of 5.2 feet per mile ( $\mathrm{ft} / \mathrm{mi})$. Most of the land contiguous to the study reach is classified as urban or developed in the downstream part of the study reach; the upstream part is mainly classified as agricultural or undeveloped (Homer and others, 2007). The Big Papillion Drainage basin is still under development, particularly the upstream part, as evidenced by a population increase in the city of Omaha of 6 percent from 408,958 to 434,353 between 2010 and 2013 (U.S. Census Bureau, 2010). The main channel within the study reach has 22 road crossings or other structures (railroad, roadway, and pedestrian bridges) as of April 2015. Levee-protected areas are between 72nd street and West Center Road (fig. 1). The levee-protected areas are included in the U.S. Army Corps of Engineers (USACE) National Levee Database (http://nld.usace.army.mil/ egis/f?p=471:1:).

\section{Previous Studies}

The most current FIS for the Big Papillion Creek Drainage basin (Federal Emergency Management Agency, 2005) was completed by the USACE in 2005 . The FIS presents estimates of the peak discharges with 10-, 2-, 1-, and 0.2-percent annual exceedance probabilities (table 2) and their associated water-surface elevations for the Big Papillion Creek at Omaha. The USACE also updated the peak discharge information for the Big Papillion Creek Drainage basin using a hydrologic model (U.S. Army Corps of Engineers, Hydrologic Engineering Branch, Engineering Division, 2011); the updated 10-, 2-, 1 -, and 0.2-percent annual exceedance probabilities from that study also are presented in table 2 . 


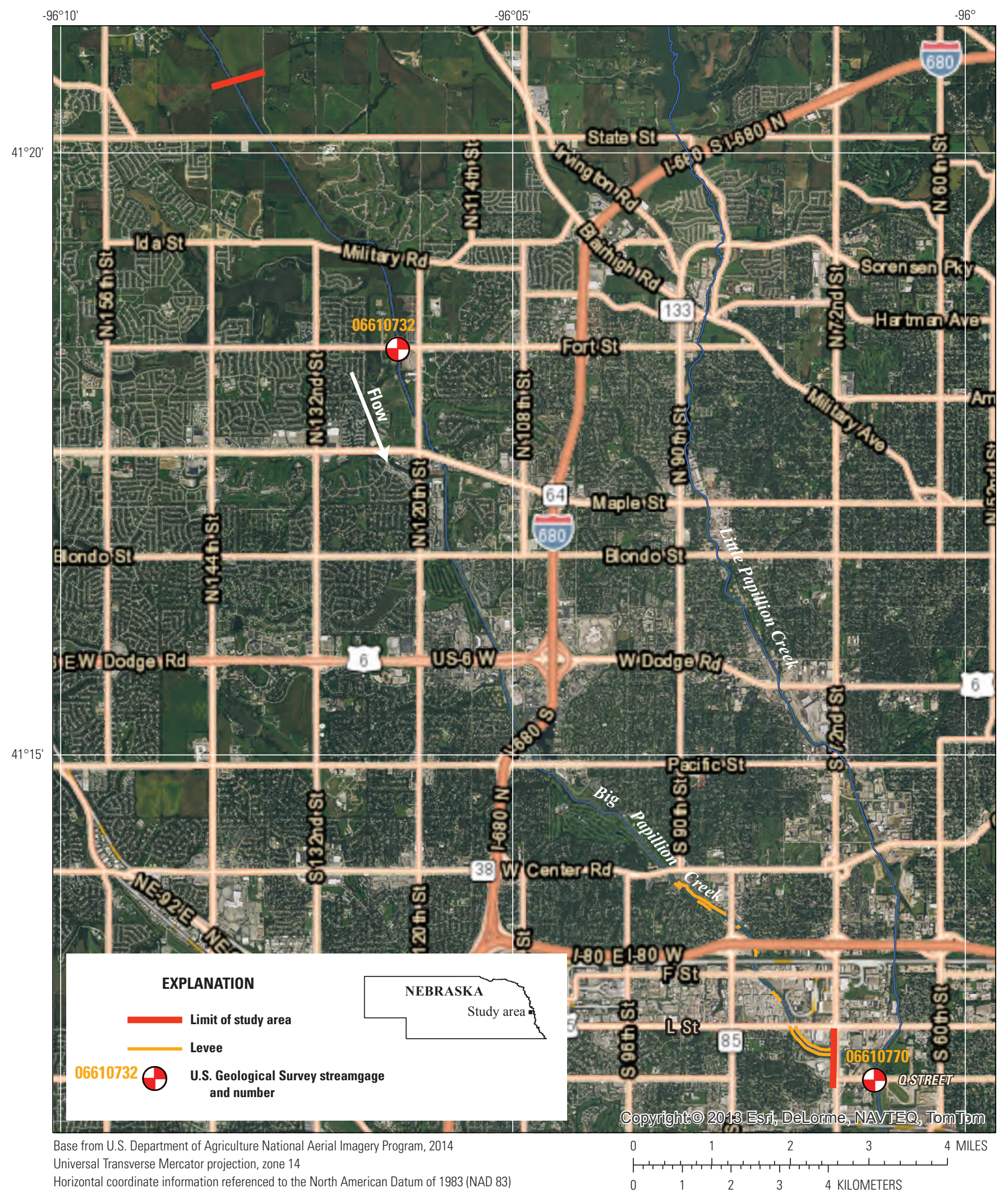

Figure 1. Location of 12.5-mile study reach for the Big Papillion Creek at Omaha, Nebraska, and location of U.S. Geological Survey streamgages. 
Table 1. U.S. Geological Survey streamgage information for Big Papillion Creek at Omaha, Nebraska.

$\left[\mathrm{mi}^{2}\right.$, square mile; ${ }^{\circ}$, degree; ', minute; ", second; NAVD 88, North American Vertical Datum of 1988; $\mathrm{ft}^{3} \mathrm{~s}$, cubic foot per second]

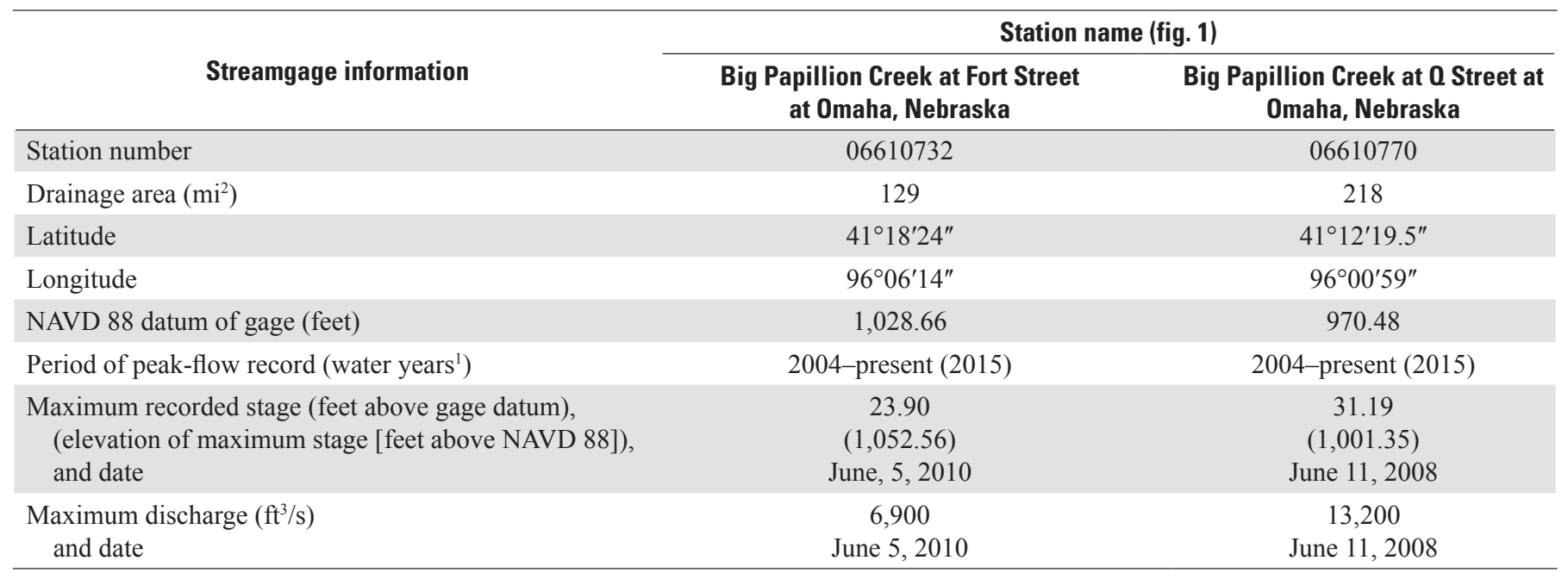

${ }^{1}$ Water year is the 12-month period from October 1 of one year through September 30 of the following year and is designated by the calendar year in which it ends.

Table 2. Peak discharges for selected annual exceedance probabilities for the Big Papillion Creek upstream from the confluence of the Big Papillion and Little Papillion Creeks.

[Data from Federal Emergency Management Agency (2005) and U.S. Army Corps of Engineers (2011). FEMA, Federal Emergency Management Agency; FIS, flood insurance study; $\mathrm{ft}^{3} / \mathrm{s}$, cubic foot per second; USACE, U.S. Army Corps of Engineers]

\begin{tabular}{ccc}
\hline $\begin{array}{c}\text { Annual } \\
\text { exceedance } \\
\text { probability } \\
\text { (percent) }\end{array}$ & $\begin{array}{c}\text { FEMA } \\
\text { FIS discharge } \\
\left.\mathbf{f t}^{3} / \mathbf{s}\right)\end{array}$ & $\begin{array}{c}\text { USACE } \\
\text { discharge } \\
\left(\mathbf{f t}^{3} / \mathbf{s}\right)\end{array}$ \\
\hline 10 & 12,400 & 14,450 \\
2 & 21,300 & 22,280 \\
1 & 25,100 & 26,770 \\
0.2 & 36,100 & 35,950 \\
\hline
\end{tabular}

\section{Creation of Flood-Inundation-Map Library}

The USGS has standardized the procedures for creating flood-inundation maps for flood-prone communities (U.S. Geological Survey, 2015c) so that the process followed and products produced are similar regardless of which USGS office is responsible for the work. Tasks specific to development of the flood maps for the study reach for the Big Papillion Creek at Fort Street were (1) acquisition of the hydraulic model that the USACE had developed for updating the 2005 FIS; (2) calibration of the hydraulic model by estimation and adjustment of energy-loss factors (roughness coefficients) in the stream channel and flood plain and determination of steady-flow data; (3) computation of water-surface profiles using the USACE Hydrologic Engineering Center's River Analysis System (HEC-RAS) computer program (U.S. Army Corps of Engineers, Hydrologic Engineering Center, 2010); (4) production of estimated flood-inundation maps at various stream stages using the USACE HEC-GeoRAS computer program (U.S. Army Corps of Engineers, Hydrologic Engineering Center, 2009) and a GIS; and (5) preparation of the maps, both as shapefile polygons that depict the areal extent of flood inundation and as depth grids that provide the depth of floodwaters, for display on a USGS flood-inundation mapping application.

\section{Computation of Water-Surface Profiles}

The water-surface profiles used to produce the 15 floodinundation maps in this study were computed by using HEC-RAS, version 4.1 (U.S. Army Corps of Engineers, Hydrologic Engineering Center, 2010). The HEC-RAS model is a one-dimensional step-backwater model for simulation of water-surface profiles with steady-state (gradually varied) or unsteady-state flow computation options. The HEC-RAS analysis for this study was done using the steady-state computation option.

\section{Hydrologic Data}

The study reach includes one streamgage (06610732; fig. 1; table 1) that has been collecting continuous water-level data since October 2007. Stage is measured every 15 minutes, 
transmitted hourly by a satellite radio in the streamgage, and made available on the Internet through the USGS National Water Information System (NWIS; U.S. Geological Survey, 2015b). Stage data from streamgage 06610732 are referenced to a local datum, but can be converted to water-surface elevations referenced to the North American Vertical Datum of 1988 (NAVD 88) by adding 1,028.66 ft. Continuous records of streamflow are computed from a stage-discharge relation developed for the streamgage; the records are available through the USGS NWIS Web site (U.S. Geological Survey, 2015a).

The peak flows used in the model simulations (table 3) were taken from the current stage-discharge relation (number 5.0, effective January 1, 2015) and corresponded with the target stages. For peak flows that were above the current stage-discharge relation (greater than 6,080 cubic feet per second $\left[\mathrm{ft}^{3} / \mathrm{s}\right]$ ), the calibrated HEC-RAS model developed for the current study was used to extend the rating. No primary tributaries join the Big Papillion Creek within the 12.5-mi study reach; however, downstream from the mapped reach, the Little Papillion Creek combines with the Big Papillion Creek upstream from the Q Street Bridge. The streamgage for the Big Papillion Creek at Q Street at Omaha, Nebraska (station 06610770, fig. 1; table 1; hereafter referred to as the Big Papillion Creek at Q Street) is downstream from the study reach and downstream from the confluence with Little Papillion Creek. A drainage area ratio of 1.69, corresponding to the ratio between the drainage areas of Big Papillion Creek at the Q Street and Fort Street streamgages, was multiplied by the discharges from the streamgage on Big Papillion Creek at Fort Street and routed in the model, in an effort to account for Little Papillion Creek inflows and capture possible backwater effects in the downstream part of the study reach.

\section{Topographic and Bathymetric Data}

All topographic data used in this study are referenced vertically to North American Vertical Datum of 1988 (NAVD 88) and horizontally to the North American Datum of 1983. Flood-inundation maps were created using a digital elevation model (DEM) that was derived from light detection and ranging (lidar) data that were collected during April 2010 by Merrick \& Co., Greenwood Village, Colorado. Post processing of these data was completed by Merrick \& Co. on August 11, 2011. The original lidar data have a horizontal resolution of $3.28 \mathrm{ft}$ (1.0 meter) and vertical accuracy of

Table 3. Estimated discharges for corresponding stages and water-surface elevations at selected locations used in the hydraulic model of the Big Papillion Creek at Fort Street at Omaha, Nebraska.

[NAVD 88, North American Vertical Datum of 1988]

\begin{tabular}{|c|c|c|c|}
\hline \multirow{2}{*}{$\begin{array}{c}\text { Stage of } \\
\text { water-surface profile } \\
\text { (foot) })^{1}\end{array}$} & \multirow{2}{*}{$\begin{array}{l}\text { Water-surface elevation } \\
\text { (foot above NAVD 88) }\end{array}$} & \multicolumn{2}{|c|}{$\begin{array}{l}\text { Estimated discharge }{ }^{2} \text { at indicated location, } \\
\text { in cubic foot per second }\end{array}$} \\
\hline & & $\begin{array}{l}\text { Upstream end of } \\
\text { study reach }\end{array}$ & $\begin{array}{l}\text { Downstream from confluence } \\
\text { with Little Papillion Creek }\end{array}$ \\
\hline 18 & $1,046.66$ & 4,400 & 7,010 \\
\hline 19 & $1,047.66$ & 4,930 & 7,880 \\
\hline 20 & $1,048.66$ & 5,490 & 8,800 \\
\hline 22 & $1,050.66$ & ${ }^{2} 6,750$ & 11,400 \\
\hline 23 & $1,051.66$ & ${ }^{27}, 660$ & 12,900 \\
\hline 24 & $1,052.66$ & ${ }^{2} 8,650$ & 14,600 \\
\hline 25 & $1,053.66$ & ${ }^{2} 9,770$ & 16,500 \\
\hline 29 & $1,057.66$ & ${ }^{2} 18,370$ & 31,000 \\
\hline 30 & $1,058.66$ & ${ }^{2} 22,170$ & 37,400 \\
\hline 31 & $1,059.66$ & ${ }^{2} 26,270$ & 44,400 \\
\hline 32 & $1,060.66$ & ${ }^{2} 30,600$ & 51,700 \\
\hline
\end{tabular}

${ }^{1}$ Water-surface profiles are 1-foot increments of stage, referenced to the streamgage datum of the U.S. Geological Survey streamgage, Big Papillion Creek at Fort Street at Omaha, Nebraska (station 06610732).

${ }^{2}$ Discharge for the stage of the water-surface profile was determined using the calibrated model to extend the rating at U.S. Geological Survey streamgage, Big Papillion Creek at Fort Street at Omaha, Nebraska (station 06610732). 
Flood-Inundation Maps for a 12.5-Mile Reach of Big Papillion Creek at Omaha, Nebraska

$1.18 \mathrm{ft}$ (36 centimeters) at a 95-percent confidence level for the "open terrain" land-cover category (root mean squared error of $0.61 \mathrm{ft}$ [18.5 centimeters]). By these criteria, the lidar data support production of 2-ft contours (Dewberry, 2012); the final DEM, which was resampled to a 6.56 -ft grid-cell size to decrease the GIS processing time, has a vertical accuracy of plus or minus $1 \mathrm{ft}$. The DEM also was used to update elevation data in cross sections where substantial changes had happened since the USACE model was originally developed.

\section{Hydraulic Structures}

A total of 22 structures, consisting of road crossings, a railroad bridge, and a pedestrian bridge, have the potential to affect water-surface elevations during floods along Big Papillion Creek in the study reach. Bridge-geometry data were obtained from a HEC-RAS model that was developed by the USACE (T. Krause, U.S. Army Corps of Engineers Omaha District, written commun., 2014). Structure information used in the hydraulic models was current as of December 2009 and verified by the USGS in April 2015.

Eight different levees line the banks of the Big Papillion Creek in the downstream part of the study reach (fig. 1). Levees line the entire length on both banks between the 72nd and L Street Bridges, and, for short, intermittent segments from L Street to West Center Road. The levees are designed to protect as high as the water level associated with the 2-percent annual exceedance probability, but do not contain all the flows simulated in this study. Because of the uncertainty as to the effectiveness of these levees, they were not simulated as a levee in the HEC-RAS model; rather, where appropriate to do so, the landward side of the levee was simulated as an ineffective flow area up to the elevation of the top of the levee. All the levees are included in the USACE National Levee Database (http://nld.usace.army.mil/egis/f?p=471:1:).

\section{Energy-Loss Factors}

Hydraulic analyses require the estimation of energy losses that result from frictional resistance exerted by a channel on flow. These frictional resistance energy losses are quantified by the Manning's roughness coefficient ( $n$ value). Initial (precalibration) Manning's roughness coefficients ( $n$ values) for energy-loss (friction-loss) calculations were estimated by comparing field photographs of the Big Papillion Creek channel and photographs of channels for which $n$ values have been computed and published in references such as Barnes (1967) and Coon (1998). A range in $n$ values from 0.028 to 0.039 was selected for the clean, low-gradient main, straightened channel. The flood plains have mixed land uses but are dominated by grass in areas adjacent to the Big Papillion Creek before transitioning to mainly urban and residential areas farther away from the creek in the flood plain. Initial $n$ values ranged from 0.04 to 0.075 for the flood plains.
As part of the calibration process, the initial $n$ values were varied by flow and adjusted using the roughness-coefficient adjustment factor tool in HEC-RAS until the differences between simulated and observed water-surface elevations at the streamgages were minimized. The actual $n$ values were computed by multiplying the initial $n$ value by each of the roughness-coefficient adjustment factors. The final $n$ values ranged from 0.023 to 0.058 for the main channel and 0.029 to 0.089 for the overbank areas simulated in this analysis.

\section{Hydraulic Model}

The HEC-RAS analysis for this study was done by using the steady-state flow computation option. Steady-state flow data consisted of flow regime, boundary conditions, and peak flows that produced water-surface elevations at the streamgage cross section that matched target water-surface elevations. These target water-surface elevations coincided with even $1-\mathrm{ft}$ increments of stage referenced to the local streamgage datum. Subcritical (tranquil) flow regime was assumed for the simulations. Normal depth, based on an estimated average bed-surface slope of 0.00049 , was used as the downstream boundary condition of the model for the simulations. The peak flows that were used in the model were described in the "Hydrologic Data" section.

The HEC-RAS model was calibrated to the current (2015) stage-discharge relation for the streamgages at Big Papillion Creek at Fort Street and Big Papillion Creek at Q Street (fig. 1, station 06610770, rating 5.0). The observed (targeted) water-surface elevations for the Big Papillion Creek at Q Street were obtained from the stage-discharge rating using the flows adjusted using the drainage area ratio as described in the "Hydrologic Data" section. Model calibration was completed by adjusting Manning's $n$ values until the results of the hydraulic computations closely agreed with the observed water-surface elevations for given flows. Differences between observed and simulated water-surface elevations for the simulated flows at the USGS streamgages for the Big Papillion Creek at Fort Street and Q Street were equal to or less than $0.01 \mathrm{ft}$ (tables 4 and 5, respectively).

\section{Development of Water-Surface Profiles}

The calibrated hydraulic model was used to generate water-surface profiles for a total of 15 stages at 1 -ft intervals between 18 and $32 \mathrm{ft}$ as referenced to the local streamgage datum of the Big Papillion Creek at Fort Street. These stages of 18 and $32 \mathrm{ft}$ correspond to elevations of 1,046.66 and $1,060.66 \mathrm{ft}$ above NAVD 88, respectively. Discharges corresponding to the various stages were obtained from the current (2015) stage-discharge relation for the streamgage on Big Papillion Creek at Fort Street. Discharges through the study reach were adjusted, as necessary, for backwater effects from Little Papillion Creek by accounting for flows at Big Papillion Creek at Q Street as described in the "Hydrologic Data" section. The estimated discharges are shown in table 3. 
Table 4. Differences between observed (target) and simulated water-surface elevations at U.S. Geological Survey streamgage on Big Papillion Creek at Fort Street at Omaha, Nebraska (station 06610732).

[NAVD 88, North American Vertical Datum of 1988]

\begin{tabular}{cccc}
\hline $\begin{array}{c}\text { Stage of } \\
\text { water-surface } \\
\text { profile } \\
\text { (foot) }\end{array}$ & $\begin{array}{c}\text { Observed (target) } \\
\text { water-surface elevation } \\
\text { (foot above NAVD 88) }\end{array}$ & $\begin{array}{c}\text { Simulated } \\
\text { water-surface } \\
\text { elevation } \\
\text { (foot above NAVD 88) }\end{array}$ & $\begin{array}{c}\text { Difference } \\
\text { in elevation } \\
\text { (foot) }\end{array}$ \\
\hline 18 & $1,046.66$ & $1,046.66$ & 0.00 \\
19 & $1,047.66$ & $1,047.66$ & 0.00 \\
20 & $1,048.66$ & $1,048.65$ & 0.01 \\
21 & $1,049.66$ & $1,049.65$ & 0.01 \\
\hline
\end{tabular}

Table 5. Differences between observed (target) and simulated water-surface elevations at U.S. Geological Survey streamgage on Big Papillion Creek at 0 Street at Omaha, Nebraska (station 06610770).

[NAVD 88, North American Vertical Datum of 1988]

\begin{tabular}{cccc}
\hline $\begin{array}{c}\text { Stage of } \\
\text { water-surface profile } \\
\text { at Fort Street streamgage } \\
\text { (foot) }\end{array}$ & $\begin{array}{c}\text { Observed (target) } \\
\text { water-surface elevation } \\
\text { (foot above NAVD 88) }\end{array}$ & $\begin{array}{c}\text { Simulated } \\
\text { water-surface } \\
\text { elevation } \\
\text { (foot above NAVD 88) }\end{array}$ & $\begin{array}{c}\text { Difference } \\
\text { in elevation } \\
\text { (foot) }\end{array}$ \\
\hline 18 & 996.89 & 996.89 & 0.00 \\
19 & 997.87 & 997.87 & 0.00 \\
20 & 998.81 & 998.80 & 0.01 \\
21 & 999.72 & 999.71 & 0.01 \\
22 & $1,000.75$ & $1,000.75$ & 0.00 \\
23 & $1,001.97$ & $1,001.97$ & 0.00 \\
\hline
\end{tabular}

\section{Development of Flood-Inundation Maps}

Flood-inundation maps were created in a GIS for the 15 water-surface profiles by combining the water-surface profiles and DEM data. The DEM data were derived from the same lidar data described in the "Topographic and Bathymetric Data" section and, therefore, have an estimated vertical accuracy of $2 \mathrm{ft}$ (that is, plus or minus $1 \mathrm{ft}$ ). Estimated flood-inundation boundaries for each simulated profile were developed with HEC-GeoRAS software (U.S. Army Corps of Engineers, Hydrologic Engineering Center, 2009), which allows the preparation of geometric data for import into HEC-RAS and processes simulation results exported from HEC-RAS (U.S. Army Corps of Engineers, Hydrologic Engineering Center, 2010). Shapefile polygons and depth grids of the inundated areas for each profile were modified, as needed, in the ArcMap application of ArcGIS (Esri, 2015) to ensure a hydraulically reasonable transition of the flood boundaries between simulated cross sections.
Any inundated areas that were detached from the main channel were examined to identify subsurface connections with the main river, such as through culverts under roadways. Where such connections existed, the mapped inundated areas were retained in their respective flood maps; otherwise, the erroneously delineated parts of the flood extent were deleted. The flood-inundation areas were overlaid on highresolution, georeferenced, aerial photographs of the study area (U.S. Department of Agriculture National Aerial Imagery Program, 2014). Bridge surfaces are displayed as inundated regardless of the actual water-surface elevation in relation to the lowest structural chord of the bridge or the bridge deck. Estimates of water depth can be obtained from the depth-grid data that are included with the presentation of the flood maps on an interactive USGS mapping application described in the following section, "Flood-Inundation Map Delivery." The flood map corresponding to the highest simulated water-surface profile, a stage of $32 \mathrm{ft}$, is presented in figure 2 . 


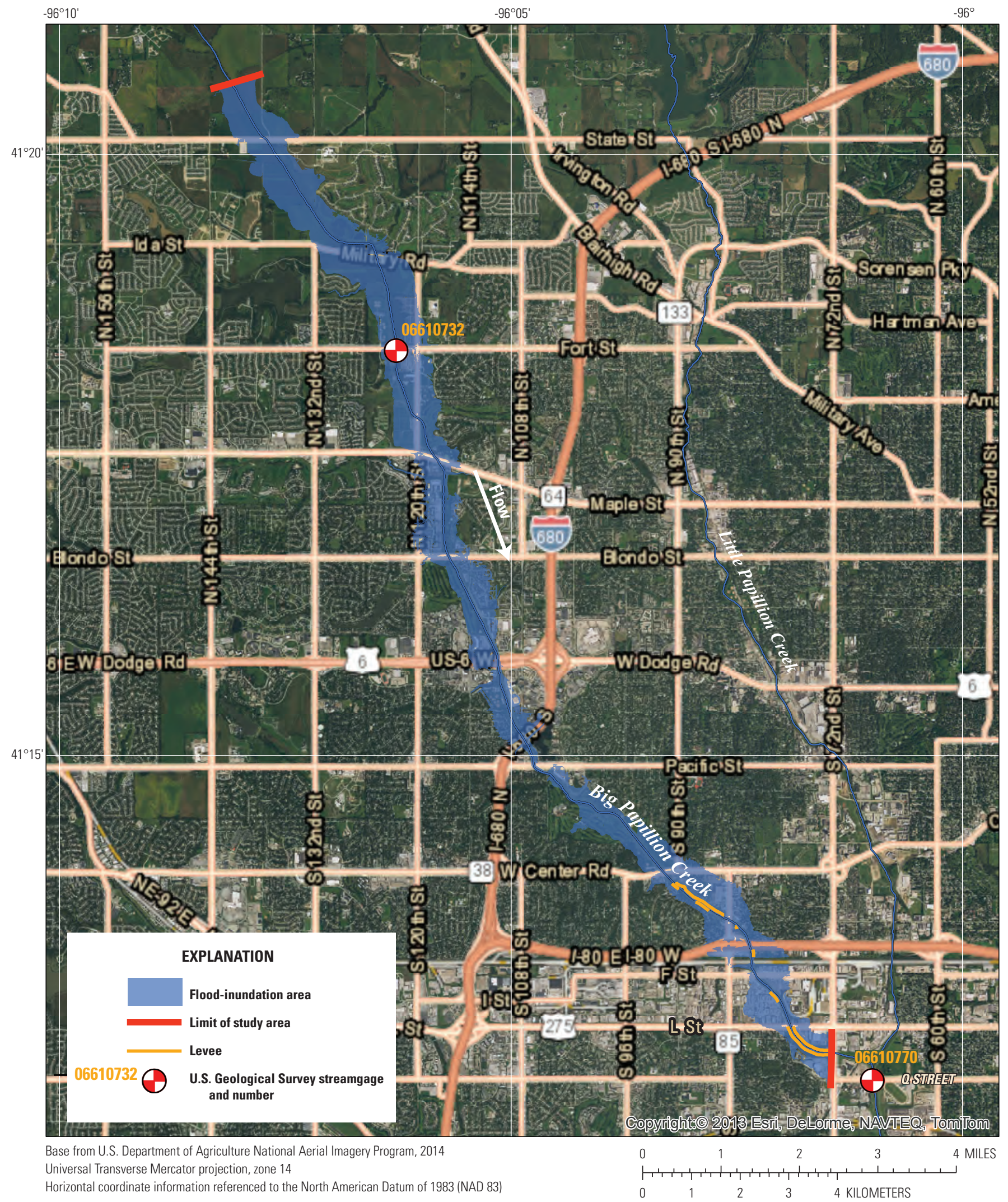

Figure 2. Flood-inundation map for the Big Papillion Creek at Fort Street at Omaha, Nebraska, corresponding to a stage of 32.00 feet at the U.S. Geological Survey streamgage (station 06610732). 


\section{Flood-Inundation Map Delivery}

Documentation from this study is available online at the USGS Publications Warehouse (http://dx.doi.org/10.3133/ sir20155152). Also, a Flood Inundation Mapping Science Web site (U.S. Geological Survey, 2015c) has been established to make USGS flood-inundation study information available to the public. The Web site links to a mapping application that presents map libraries and provides detailed information on flood extents and depths for simulated sites. The mapping application enables the production of customized floodinundation maps from the map library for Big Papillion Creek at Fort Street (station 06610732). A link on the Flood Inundation Mapping Science Web site connects to the USGS NWIS (U.S. Geological Survey, 2015a), to obtain current stage and streamflow at the USGS streamgage 06610732. A second link connects to the NWS AHPS Web site (National Weather Service, 2015a) so that the user can obtain applicable information on forecasted peak stage. The estimated flood-inundation maps are displayed in sufficient detail so that preparations for flooding and decisions for emergency response can be completed efficiently. Depending on the flood magnitude, roadways are shown as shaded (inundated and likely impassable) or not shaded (dry and passable) to facilitate emergency planning and use. Bridges are shaded - that is, shown as inundated — regardless of the flood magnitude. A shaded building should not be interpreted to mean that the structure is completely submerged, rather that bare-earth surfaces in the vicinity of the building are inundated. In bare-earth cases, the water depth (as indicated in the mapping application by holding the cursor over an inundated area) near the building would be an estimate of the water level inside the structure unless flood-proofing measures had been implemented.

\section{Disclaimer for Flood-Inundation Maps}

The flood-inundation maps should not be used for navigation, regulatory, permitting, or other legal purposes. The USGS provides these maps "as-is" for a quick reference, emergency planning tool but assumes no legal liability or responsibility resulting from the use of this information.

\section{Uncertainties and Limitations Regarding Use of Flood-Inundation Maps}

Although the flood-inundation maps represent the boundaries of inundated areas with a distinct line, some uncertainty is associated with these maps. The flood boundaries shown were estimated on the basis of water stages and streamflows at selected USGS stream gages. Water-surface elevations along the stream reaches were estimated by steady-state hydraulic modeling, assuming unobstructed flow, and using streamflows and hydrologic conditions anticipated at the USGS streamgage(s). The hydraulic model reflects the land-cover characteristics and any bridge, dam, levee, or other hydraulic structures existing as of April 2015. Unique meteorological factors (timing and distribution of precipitation) may cause actual streamflows along the modeled reach to vary from those assumed during a flood, which may lead to deviations in the water-surface elevations and inundation boundaries shown. Additional areas may be flooded due to unanticipated conditions such as changes in the streambed elevation or roughness, backwater into major tributaries along a main-stem river, or backwater from localized debris or ice jams. The accuracy of the floodwater extent portrayed on these maps will vary with the accuracy of the digital elevation model used to simulate the land surface.

If this series of flood-inundation maps will be used in conjunction with NWS river forecasts, the user should be aware of additional uncertainties that may be inherent or factored into NWS forecast procedures. The NWS uses forecast models to estimate the quantity and timing of water flowing through selected stream reaches in the United States. These forecast models (1) estimate the amount of runoff generated by precipitation and snowmelt, (2) simulate the movement of floodwater as it proceeds downstream, and (3) predict the flow and stage (and water-surface elevation) for the stream at a given location (AHPS forecast point) throughout the forecast period (every 6 hours and 3 to 5 days out in many locations). For more information on AHPS forecasts, please see: http:// water.weather.gov/ahps/pcpn_and_river_forecasting.pdf.

Another source of uncertainty relevant to the study reach for the Big Papillion Creek at Fort Street is that the downstream portions of the maps from the F Street Bridge to the 72nd Street Bridge have higher levels of uncertainty because of possible variable backwater from the confluence of the Big Papillion and Little Papillion Creeks upstream from the Q Street Bridge. Input flows were adjusted in the hydraulic model using a drainage area ratio; however, because of variation in rainfall in the drainage basin, the flow contribution from the Little Papillion Creek may be different than the drainage area ratio that was used in the model and, therefore, the water surface and resulting maps in this area have a greater uncertainty. When flows greater than $20,000 \mathrm{ft}^{3} / \mathrm{s}$ occur at the Big Papillion Creek at Q Street streamgage, backwater effects begin to propagate upstream in the model and affect the profiles in this area. Additional uncertainties and limitations pertinent to this study may be described elsewhere in this report. 


\section{Summary}

A series of 15 digital flood-inundation maps were developed by the U.S. Geological Survey, in cooperation with the Papio-Missouri River Natural Resource District, for the Big Papillion Creek at Omaha, Nebraska. The maps cover a 12.5-mile study reach of the Big Papillion Creek from 0.6 mile upstream from the State Street Bridge to the 72nd Street Bridge that crosses the Big Papillion Creek. The maps were developed using the U.S. Army Corps of Engineers Hydrologic Engineering Center's River Analysis System and HEC-GeoRAS programs to compute water-surface profiles and delineate estimated flood-inundation areas and depths of flooding for selected stream stages. The Hydrologic Engineering Center's River Analysis System hydraulic model was calibrated to the current stage-discharge relations at streamgages for the Big Papillion Creek at Fort Street and the Big Papillion Creek at Q Street. The model was used to compute 15 watersurface profiles for flood stages at 1-foot intervals referenced to the streamgage datum and ranging from 18 feet (or near bankfull) to 32 feet, which exceeds the stage of the maximum recorded peak flow and the "major flood stage" as defined by the National Weather Service. The simulated water-surface profiles were then combined with a Geographic Information System digital elevation model derived from light detection and ranging data to delineate estimated flood-inundation areas as shapefile polygons and depth grids for each profile. These flood-inundation polygons were overlaid on high-resolution, georeferenced, aerial photographs of the study area. The flood maps are available through a mapping application that can be accessed on the U.S. Geological Survey Flood Inundation Mapping Science Web site (http://water.usgs.gov/osw/ flood_inundation).

Interactive use of the maps on this mapping application can give users a general indication of depth of water at any point by using the mouse cursor to click within the shaded areas. These maps, in conjunction with the real-time stage data from the U.S. Geological Survey streamgage, Big Papillion Creek at Fort Street at Omaha, Nebraska (station 06610732), and forecasted flood stage data from the National Weather Service Advanced Hydrologic Prediction Service, will help to guide the general public in taking individual safety precautions and provide emergency management personnel with a tool to efficiently manage emergency flood operations and postflood recovery efforts.

\section{References Cited}

Barnes, H.H., Jr., 1967, Roughness characteristics of natural channels: U.S. Geological Survey Water-Supply Paper 1849, 213 p. [Also available at http://pubs.usgs.gov/wsp/ wsp_1849/pdf/wsp_1849.pdf.]

Coon, W.F., 1998, Estimation of roughness coefficients for natural stream channels with vegetated banks: U.S. Geological Survey Water-Supply Paper 2441, 133 p. [Also available at http://pubs.usgs.gov/wsp/2441/report.pdf.]

Dewberry, 2012, National Enhanced Elevation Assessment: Fairfax, Va., 84 p., accessed July 9, 2013, at http://www. dewberry.com/docs/default-source/documents/neea_finalreport_revised-3-29-12.pdf?sfvrsn $=0$.

Esri, 2015, ArcGIS: Esri, accessed May 5, 2015, at http:// www.esri.com/software/arcgis/.

Federal Emergency Management Agency, 2005 Flood Insurance Study, Douglas County, Nebraska, and incorporated areas: Washington, D.C., Federal Emergency Management Agency, 66 p., 53 pl.

Homer, C., Dewitz, J., Fry, J., Coan, M., Hossain, N., Larson, C., Herold, N., McKerrow, A., VanDriel, J.N., and Wickham, J., 2007, Completion of the 2001 National Land Cover Database for the conterminous United States: Photogrammetric Engineering and Remote Sensing, v. 73, no. 4, p. 337-341.

National Weather Service, 2015a, Advanced Hydrologic Prediction Service-Big Papillion Creek at Fort Street at Omaha: Valley, Nebr., National Weather Service, Omaha/Valley Weather Forecast Office, accessed April 9, 2015, at http://water.weather.gov/ahps2/hydrograph. php? $w f o=$ oax \&gage $=$ ohan 1 .

National Weather Service, 2015b, National Weather Service glossary: Silver Spring, Md., U.S. Department of Commerce, National Oceanic and Atmospheric Administration, National Weather Service, accessed April 9, 2015, at http:// w1.weather.gov/glossary/index.php?word=action+stage.

Omernik, J.M., 1987, Ecoregions of the conterminous United States: Annals of the Association of American Geographers, v. 77, no. 1, p. 118-125. [Also available at http://dx.doi. org/10.1111/j.1467-8306.1987.tb00149.x.] 
Papio-Missouri River Natural Resources District, 2015, It happened here before: Papio-Missouri River Natural Resources District, accessed April 9, 2015, at http://www.papionrd.org/ flood-control/it-happened-here-before/.

U.S. Army Corps of Engineers, Hydrologic Engineering Branch, Engineering Division, 2011, Papillion Creek Drainage basin Nebraska hydrologic analysis: U.S. Army Corps of Engineers, 152 p.

U.S. Army Corps of Engineers, Hydrologic Engineering Center, 2009, HEC-GeoRAS - GIS tools for support of HECRAS using ArcGIS-User's manual (ver. 4.2): Davis, Calif., U.S. Army Corps of Engineers, CPD-83, 246 p. [Also available at http://www.hec.usace.army.mil/software/hec-georas/ documentation/HEC-GeoRAS42_UsersManual.pdf.]

U.S. Army Corps of Engineers, Hydrologic Engineering Center, 2010, HEC-RAS, river analysis system hydraulic reference manual (ver. 4.1): Davis, Calif., U.S. Army Corps of Engineers, CPD-69, 411 p. [Also available at http:// www.hec.usace.army.mil/software/hec-ras/documentation/ HEC-RAS_4.1_Reference_Manual.pdf.]

U.S. Census Bureau, 2010, American FactFinder: U.S. Department of Commerce, U.S. Census Bureau, accessed April 28, 2015, at http://factfinder2.census.gov.

U.S. Department of Agriculture National Aerial Imagery Program, 2014, Nebraska Digital Orthorectified Images (DOQ), Department of Agriculture (USDA), Farm Service Agency (FSA), Aerial Photography Field Office (APFO).

U.S. Geological Survey, 2015a, USGS 06610732 Big Papillion Creek at Fort Street at Omaha, Nebr.: U.S. Geological Survey, National Water Information System, accessed May 6, 2015, at http://waterdata.usgs.gov/ne/nwis/uv?06610732.

U.S. Geological Survey, 2015b, USGS surface-water data for the Nation: U.S. Geological Survey, National Water Information System, accessed April 9, 2015, at http://waterdata. usgs.gov/nwis/sw.

U.S. Geological Survey, 2015c, USGS flood inundation mapping science - Flood inundation mapping (FIM) program: U.S. Geological Survey, accessed April 9, 2015, at http:// water.usgs.gov/osw/flood_inundation. 
Publishing support provided by: Rolla Publishing Service Center

For more information concerning this publication, contact: Director, USGS Nebraska Water Science Center 5231 South 19th Street

Lincoln, NE 68512

(402) 328-4100

Or visit the Nebraska Water Science Center Web site at: http://ne.water.usgs.gov 



\section{$\frac{\mathbb{3}}{3}$}

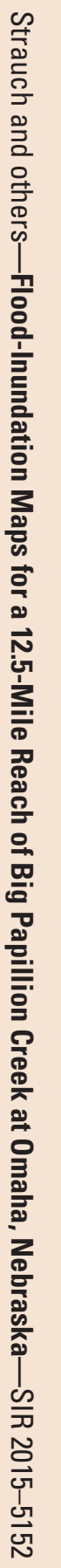

